\title{
COMPARISON OF OPERATION OF KAUNAS AND KLAIPĖDA WWTPS DIGESTERS
}

Midona DAPKIENĖ, Institute of Hydraulic Construction Engineering, Aleksandras Stulginskis University, Universiteto g. 10, LT-53361, Akademija, Kaunas raj., midona.dapkiene@asu.lt

Laima ČESONIENĖ, Institute of Environment and Ecology, Aleksandras Stulginskis University, Studentu g. 11, LT-53361, Akademija, Kaunas raj., laima.cesoniene@asu.lt (corresponding author)

Tomas PILIPAUSKAS, Institute of Hydraulic Engineering, Aleksandras Stulginskis University, Universiteto g. 10, LT-53361, Akademija, Kaunas raj., tomas.pilipauskas@ gmail.com

The article provides comparison of operation of digesters for 2014, installed in wastewater treatment plants (WWTP) of two Lithuanian cities Kaunas and Klaipeda. It was established that the temperature and decomposition degree of organic materials had impact on biogas discharge in digesters of both wastewater treatment plants. Increase of these technological parameters resulted in increase of biogas output. Actual output of biogas of Kaunas wastewater treatment plant digester was by $5.8 \%$ less than theoretical output, in Klaipeda WWTP anaerobic reactor - by $4.2 \%$. After comparison of biogas discharge generated from $1 \mathrm{~m}^{3}$ of sludge in Kaunas and Klaipeda WWTPs it was established that the efficiency of Klaipeda WWTP digester exceeded the efficiency of Kaunas WWTP reactor by $7 \%$.

Keywords: biogas, digester, decomposition degree of organic materials, temperature.

\section{INTRODUCTION}

Sludge amount gradually increases while distributing wastewater collection systems in cities and other urban areas and improving their treatment efficiency. Wastewater sludge disposal problem is faced not only in Lithuania, but also in other advanced countries.

Sludge treatment purpose is to decrease the content of organic matter and sludge. Anaerobic degradation is an important sludge treatment process part, during which a part of organic compound contained in biomass is formed as the result of activity of various microorganisms, and as the result biogas - an environmentally friendly fuel, mainly consisting of carbon dioxide and methane, is formed. Therefore, anaerobic digestion is an energy generating process (Appels et al., 2008).

In large EU countries wastewater sludge has not been considered waste for a long time, it is a fuel used for energy generation. Biogas generation is especially distributed in Denmark, Austria, Germany and South-Eastern Sweden. As for the countries which joined the EU recently, a great amount of total gas production is generated in wastewater treatment plants of Slovak Republic - $91 \%$, Poland - 59\%, Hungary - $34 \%$. Less biogas amounts are generated in WWTP of Czech Republic (26\%) and the Republic of Slovenia (13\%) (Bodik et al., 2011).

In 2012 in Lithuania was generated over 45 thousand tons of wastewater sludge, about $15 \mathrm{~kg}$ of sludge (dry matters) per capita. State list of projects which includes the EU-funded projects throughout Lithuania drawn up. There are 23 sludge management facilities: 12 sewage sludge digestion and drying equipment, 2 drying equipment and 9 of the composting site (Environmental protection agency..., 2014).

The energetic efficiency of sludge digestion process depends on a number of technological factors. While operating digesters it is highly important to maintain optimum conditions, required for maximum biogas output after digestion.

Temperature is a very important parameter, which has impact on anaerobic processes (Mathai and Turovskiy, 2006). Anaerobic sludge digestion can occur in three temperature modes: under psychrophilic $15-25{ }^{\circ} \mathrm{C}$, mesophilic 20-45 ${ }^{\circ} \mathrm{C}$ and thermophilic $50-65{ }^{\circ} \mathrm{C}$ temperature. Optimum digestion temperature depends on the composition of digested sludge and digester type, but the required temperature shall be maintained in the majority of reactions in progress in the reactor, so that to ensure efficient and smooth gas generation.

Anaerobic digesters functioning on mesophilic mode are more widespread because they work at lower temperature scale, require less heat and the process is more stable due to bacterial diversity (Monnet, 2003).

Decomposition of organic materials is a permanent process. During this process complex organic compounds form simple compounds available for further processes ((Budrys and Liužinas, 2005; Suresh at al., 1996).

Copyright (C) 2015 The Authors. Published by Aleksandras Stulginskis University. This is an open-access article distributed under the terms of the Creative Commons Attribution License (CC-BY 4.0), which permits unrestricted use, distribution, and reproduction in any medium, provided the original author and source are credited. 
To get the greatest possible yield of biogas composition of sludge supplied to digester needs to be controlled. Mixing in some household waste water increased biogas release by 10-15\%. Mixing household waste water sludge with different waste possibly improves microorganism activity, speeds up sludge digestion process and increases energy production from methane (Kabouris et al., 2008; Davidsson et al., 2007).

To achieve optimal sludge outcome appropriate stirring of sludge is essential. Stirring ensures that contact between sludge and active biomass are maintained, equal temperature is kept, contents of active biomass is held even, other biological and physical factors inside the reactor. Different stirring techniques are used worldwide. The most common of them are stirring in a mechanic way and hydraulic without the use the stirrer (Baere, 2006). Lithuania uses mechanical agitators for sludge mixing, installed inside a digestion tank.

This paper objective is to evaluate the impact of technological parameters on biogas output in wastewater treatment plants of Kaunas and Klaipeda.

\section{THE OBJECT AND METHODOLOGY OF RESEARCH}

Wastewater sludge forms in primary and secondary sedimentation tanks. In average $530 \mathrm{~m}^{3}$ of sludge per day is supplied to digesters of Kaunas wastewater treatment plant, and $405 \mathrm{~m}^{3}$ of sludge - to Klaipeda WWTP anaerobic reactors.

To digest sludge Kaunas wastewater treatment plant uses two digesters with the volume of $8800 \mathrm{~m}^{3}$ each. In Klaipeda wastewater treatment plant the sludge is also digested in two digestion tanks (the capacity of each is $3000 \mathrm{~m}^{3}$ ). Digesters of Kaunas and Klaipèda WWTPs function in mesophilic mode.

Digesters of Kaunas WWTP are equipped with mechanical mixers with one blade. The mixer operates 24 hours per day, rotates one way, and there is horizontal mixing process. There is no reverse mode. According to the project the reactor had to be equipped with panels for efficiency improvement. Due to absence of panels the sludge accumulates in side areas and is not mixed. The volume of anaerobic digestion tank decreases.

For sludge mixing Klaipeda WWTP uses a slow-speed mixer. Inside the digester there is a pipe, to which the sludge is pushed, so there is vertical mixing process in both parts of the pipe. This mixer has reverse rotation option. Advantages of this type of mixer are as follows: more effective mixing in the whole tank, low chance of formation of floating substances and sediments.

In the course of the research technical characteristics that could affect output of biogas in digesters were observed. Such characteristics included discharge of primary and surplus sludge supplied, temperature and decomposition degree of organic materials.

Analysis of digestion tanks of Kaunas and Klaipeda wastewater treatment plants were carried out during 2014 year, 7-8 times per month (total 92 day test data were analysed).

In order to evaluate the efficiency of digesters of Kaunas and Klaipeda WWTPs, it is necessary to know theoretical and actual biogas discharges. Theoretical biogas discharge is maximum gas amount, which may be generated from the sludge, supplied to the digester.

Discharges of primary and surplus sludge were measured with electromagnetic flowmeters Promag 30. Temperature of sludge digested in reactors was measured with thermometers Omnigrad TST 111. Discharge of released biogas was determined with gas flowmeters AF 88.

The degradation degree of organic materials was found from theoretical timetable using values of sludge ash contents before and after digestion (Figure 1). The bigger the difference between sludge ash contents before and after digestion, the better certain organic materials decompose releasing a greater amount of biogas.

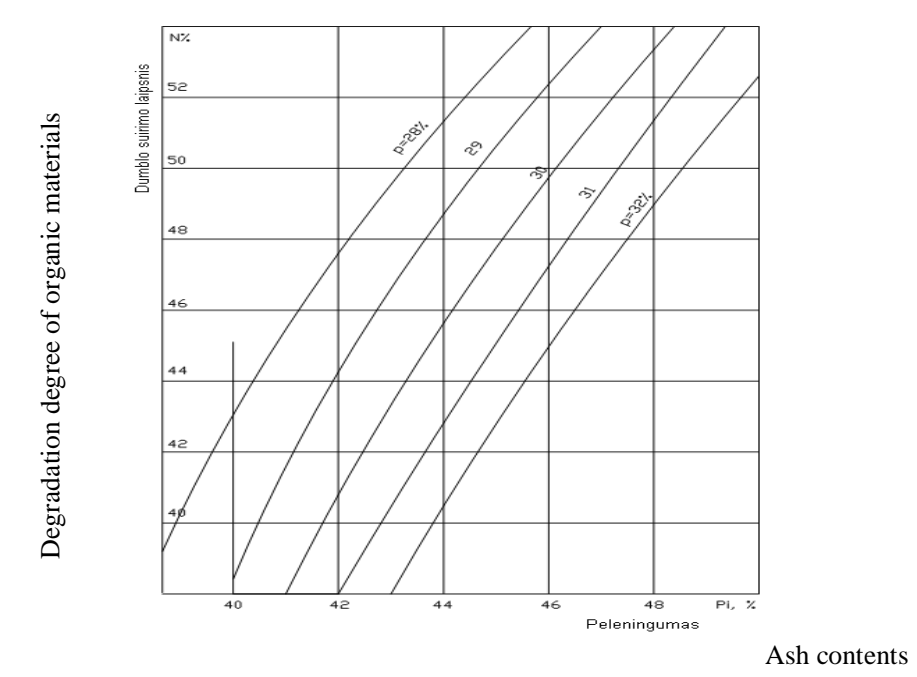

Figure 1. Decomposition degree of organic materials in the digestion process 
According to amount of organic materials and decomposition degree theoretical discharge of biogas was determined (Figure 2).

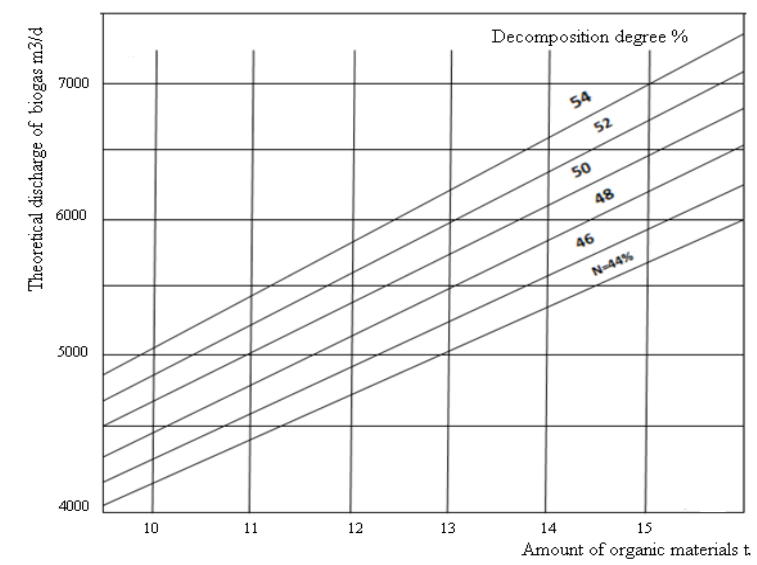

Figure 2. Determination of theoretical discharge of biogas

SPSS 10.0 software was used for determination of correlation coefficients of biogas discharge and temperature, and decomposition degree of organic materials. Temperature and decomposition degree impact on biogas discharge was calculated using multiple linear regression. Multiple regression was used for analysis of dependence between regressands (biogas discharge) and regressors (temperature and decomposition degree of organic materials), when the values of foreign non-related factors are considered constant (Rothman and Green, 1998). Multiple regression models can be used for forecasting, when all regressors do not mutually correlate. Multiple linear regression is

$$
Y_{i}=a+b_{1} x_{1} i+b_{2} x_{2} i+\ldots .+b_{k} x_{k i}
$$

here $\quad Y_{i}$ - regressand (biogas discharge);

$a$ - constant;

$b$ - non-standardized coefficient;

$x$ - regressors (temperature and decomposition degree of organic materials).

\section{RESULTS OF THE RESEARCH}

Temperature, supplied sludge discharge changes, contained organic matter has maximum impact on biogas generation. The amount of sludge, supplied to digestion tanks, cannot be regulated, because this can interrupt the treatment process. Organic materials content in sludge depends on the composition of wastewater, collected in the wastewater treatment plant.

Temperature range for operation of digesters specified in the literature is $35-37^{\circ} \mathrm{C}$ (Gerardi, 2003).

In 2014 in digestion tanks of Kaunas WWTP temperature oscillated between $33.5-35.2{ }^{\circ} \mathrm{C}$. Operating temperature in reactors of Klaipèda WWTP oscillated between $33.9-34.9{ }^{\circ} \mathrm{C}$.

Biogas discharge dependence on temperature in digestion tanks of Kaunas and Klaipeda WWTP is provided in Figure 3.

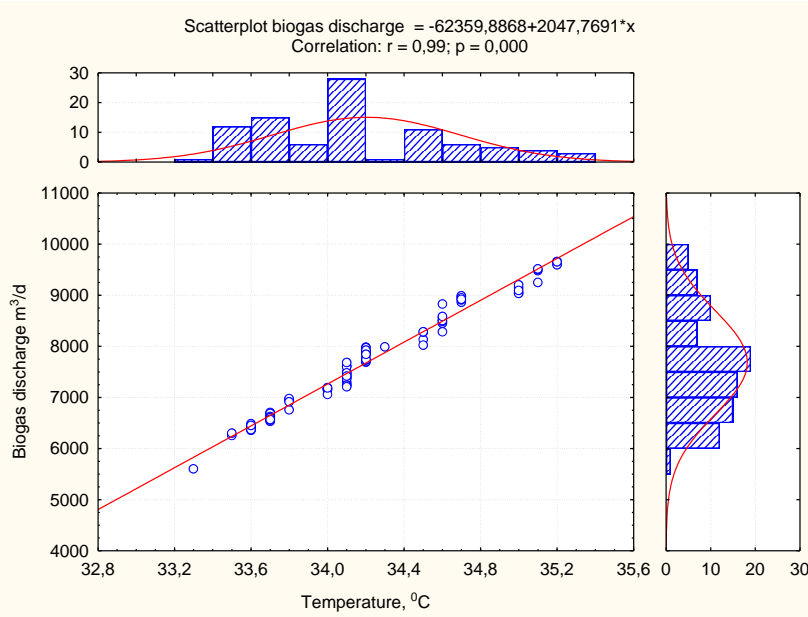

a

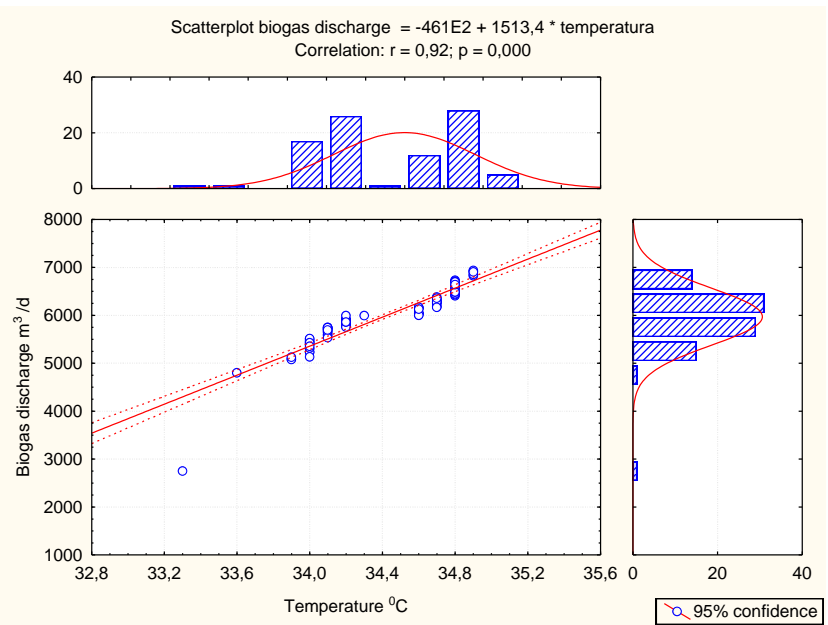

b

Figure 3. Dependence of biogas discharge on temperature in Kaunas (a) and Klaipeda (b) WWTPs digesters 
Correlation coefficients were calculated for the purpose of determination of the relation between biogas yield and temperature. Confidence level is $\mathrm{p}<0.05$. Strong, statically reliable relation $(\mathrm{p}=0.00)$ was obtained between temperature and biogas discharge in digesters of both Kaunas and Klaipeda WWTPs. Increase of temperature resulted in increase of biogas output.

It can be seen from histograms of figure 1 that maximum biogas amount was generated when the digestion tank of Kaunas WWTP operated under the temperature range of $34.0-34.2^{\circ} \mathrm{C}$. As for the digester of Klaipeda WWTP, we can see two temperature modes $-34.1-34.3{ }^{\circ} \mathrm{C}$ or $34.8-35.0^{\circ} \mathrm{C}$. Therefore, these temperature ranges are similar in reactors of both wastewater treatment plants.

Biogas discharge dependence on the decomposition degree of organic materials is shown in Figure 4.

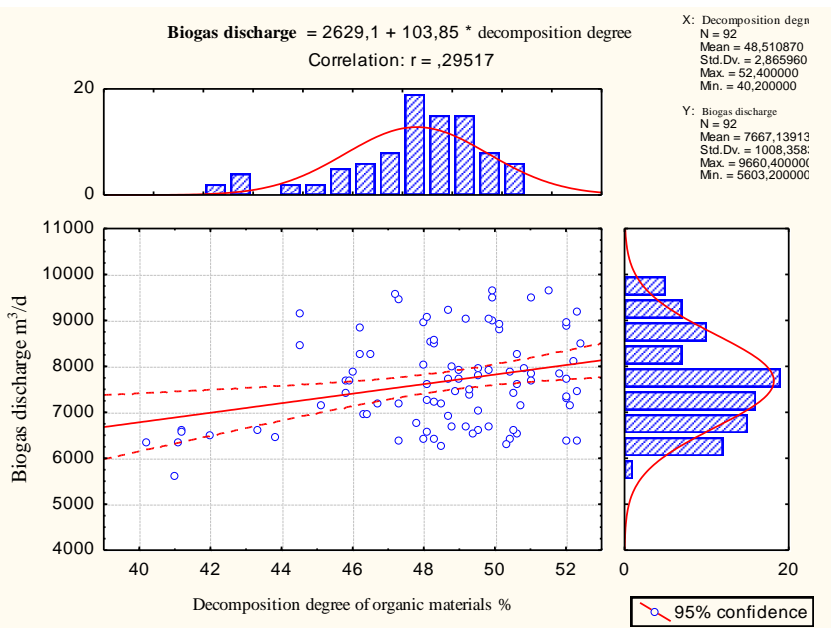

a
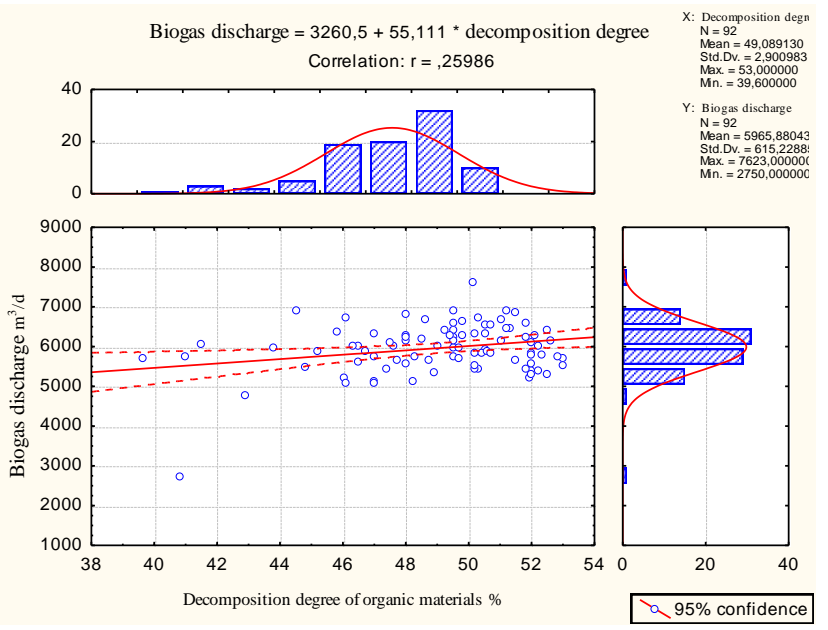

b

Figure 4. Dependence of biogas discharge on decomposition degree of organic materials in Kaunas (a) and Klaipeda (b) WWTPs digesters

Correlation is statistically reliable therefore it is possible to state that biogas discharge is dependent on decomposition degree of organic materials. Increase of decomposition degree resulted in increase of generated biogas discharge.

Maximum biogas discharge (9660 $\left.\mathrm{m}^{3} / \mathrm{day}\right)$ was obtained in the digestion tank of Kaunas WWTP when decomposition degree of organic materials was $51.5 \%$. Maximum amount of biogas was generated when decomposition degree varied within the range of 47.5-48.2\%. Maximum amount of biogas (7623 $\mathrm{m}^{3} /$ day) was generated in the reactor of Klaipeda WWTP when decomposition degree of organic materials was $50.1 \%$. Maximum output of biogas was generated when decomposition degree reached from 48.5 to $49.5 \%$. As it can be seen, decomposition degree of organic materials, under which maximum amount of biogas was generated in digesters of both wastewater treatment plants, are similar, and the difference in the range, within which maximum amount of biogas was generated, was insignificant.

The method of multiple regression analysis was used for evaluation of impact of temperature and decomposition degree of organic materials on biogas discharge in digesters of Kaunas and Klaipèda WWTPs (Table 1).

Table 1. Impact of temperature and decomposition degree of organic materials on biogas discharge $(Y)$ in digesters of Kaunas and Klaipèda WWTPs

\begin{tabular}{|c|c|c|c|c|c|c|}
\hline & & \multicolumn{2}{|c|}{ Unstandardized coefficients } & Standardized coefficients & \multirow[b]{2}{*}{$t$} & \multirow[b]{2}{*}{ Sig. } \\
\hline & & $B$ & Std. error & Beta & & \\
\hline \multicolumn{7}{|c|}{ (Y) Biogas discharge $\mathrm{m}^{3} / \mathrm{d}$ (Kaunas WWTP digester) } \\
\hline \multirow[t]{3}{*}{1} & Constant & $-62581,946$ & 1025,414 & & $-61,031$ & 0,000 \\
\hline & $\left(X_{I}\right)$ Temperature ${ }^{\circ} \mathrm{C}$ & $\left(b_{1}\right) 2045,649$ & 31,221 & 0,986 & 65,521 & 0,000 \\
\hline & $\left(X_{2}\right)$ Decomposition degree $\%$ & $\left(b_{2}\right) 6,118$ & 5,293 & 0,017 & 1,156 & 0,049 \\
\hline \multicolumn{7}{|c|}{ (Y) Biogas discharge $\mathrm{m}^{3} / \mathrm{d}$ (Klaipèda WWTP digester) } \\
\hline 2 & $\begin{array}{l}\text { Constant } \\
\left(X_{1}\right) \text { Temperature }{ }^{\circ} \mathrm{C} \\
\left(X_{2}\right) \text { Decomposition degree \% }\end{array}$ & $\begin{array}{l}-47674,106 \\
\left(b_{1}\right) 1529,987 \\
\left(b_{2}\right) 20,575\end{array}$ & $\begin{array}{c}2201,007 \\
65,029 \\
8,211\end{array}$ & $\begin{array}{l}0,911 \\
0,097\end{array}$ & $\begin{array}{c}-21,660 \\
23,528 \\
2,506\end{array}$ & $\begin{array}{l}0,000 \\
0,000 \\
0,014\end{array}$ \\
\hline
\end{tabular}

$x_{k}$ are fixed $t$-student criteria for determination of static difference of coefficients $b_{j}$ from zero, and then it shall be decided whether the expected values depend on $x_{j}$. Standardized coefficients Beta are used for determination of relative impact of regressors on the expected $Y$. Greater Beta coefficient demonstrates greater $Y$ dependence on $x_{j}$.

Multiple regression analysis of temperature and degradation rate impact on biogas discharge demonstrated that both factors have impact on biogas discharge, however all coefficients show that temperature has greater impact, that decomposition degree of organic materials. 
The values of theoretical and actual biogas discharges in 2014 in digesters of Kaunas and Klaipėda WWTPs, were compared (Figure 5).

Theoretical biogas discharge will be always greater than actual one, because it is calculated when organic matter degrades under ideal conditions. However it is very difficult to maintain such conditions, because of change of temperature, mixing and sludge composition. Due to this reason actually generated biogas amounts are less. Average annual efficiency of the digester of Klaipeda WWTP in 2014 was $95.8 \%$, average annual efficiency of similar facility in Kaunas WWTP was $94.2 \%$. Operation efficiency of the reactors could be improved by maintaining as stable conditions as possible, required for ensuring of smooth anaerobic process.

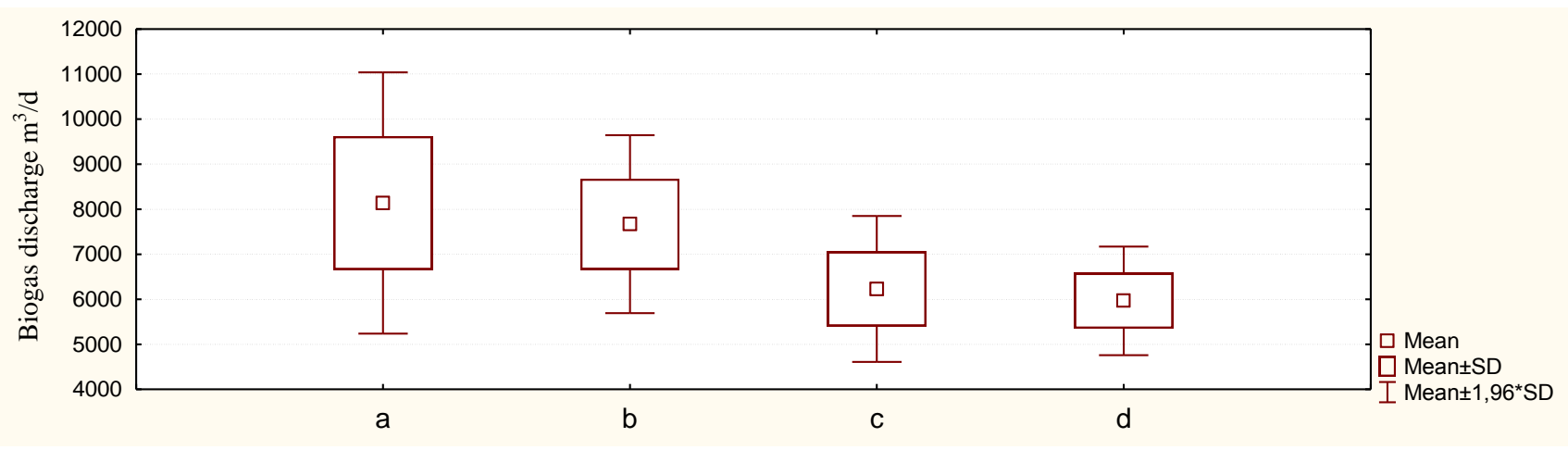

Figure 5. Discharges of biogas in digesters: a - Kaunas WWTP theoretical, b - Kaunas WWTP actual, c - Klaipeda WWTP theoretical, d - Klaipèda WWTP actual

The amount of biogas generated in the reactors from $1 \mathrm{~m}^{3}$ of sludge was calculated for the purpose of comparison of efficiency of digesters of Kaunas and Klaipeda wastewater treatment plants. Average amount of biogas generated from $1 \mathrm{~m}^{3}$ of sludge was $14.44 \mathrm{~m}^{3}$ of biogas in Kaunas WWTP digester and $15.37 \mathrm{~m}^{3}$ in Klaipeda WWTP reactor, so it can be stated that digester of Klaipeda WWTP operated more effectively in 2014.

\section{CONCLUSIONS}

1. Temperature and decomposition degree of organic materials have impact on biogas generation of digesters. Increase of these technological parameters results in increase of biogas output. Multiple regression analysis of temperature and decomposition degree impact on biogas discharge demonstrated that both factors have impact on biogas output, however all coefficients show that temperature has greater impact, that decomposition degree of organic materials.

2. Maximum biogas amount generated in digesters of Kaunas and Klaipeda WWTPs was reached during operation within similar temperature range. The difference in the degree of organic materials decomposition, within which maximum amount of biogas was generated, was insignificant: in the digestion tank of Kaunas WWTP $-47.5-48.2 \%$; in the reactor of Klaipeda WWTP $-48.5-49.5 \%$.

3. Actual discharge of biogas of Kaunas WWTP was by $5.8 \%$ less than theoretical discharge, Klaipeda WWTP reactor - by $4.2 \%$. Operation efficiency of the reactors could be improved by maintaining as stable conditions as possible, required for ensuring of smooth anaerobic process.

4. After comparison of amounts of biogas generated from $1 \mathrm{~m}^{3}$ of sludge in digesters of Kaunas and Klaipeda WWTPs it can be stated that anaerobic reactors of Klaipeda WWTP operated effectively by $7 \%$ in 2014 .

\section{REFERENCES}

1. Appels, L., Baeyens, J., Degrève, J., Dewil, R. 2008. Principles and potential of the anaerobic digestion of waste-activated sludge. Progress in Energy and Combustion Science, Vol. 34, Iss. 6, pp.755-781. http://dx.doi.org/10.1016/j.pecs.2008.06.002

2. Baere, de L. 2006. The Dranco technology: a unique digestion technology for solid organic waste. Organic waster systems, pp. 1-8.

3. Bodík, I., Sedláèek, S., Kubaská, M., Hutòan, M. 2011. Biogas Production in Municipal Wastewater Treatment Plants - Current Status in EU with a Focus on the Slovak Republic. Chemical \& Biochemical Engineering Quarterly, Vol. 25, Iss. 3, pp. 335-340.

4. Budrys, R., Liužinas, R. 2005. Liquid waste and wastewater in agriculture. Technical solutions of management. Soil Remediation Technology. Public body, Vilnius.

5. Davidsson, A., Jansen, J., Appelqvist, B., Gruvberger, C., Hallmer, M. 2007. Anaerobic digestion potential of urban organic waste: a case study in Malmö. Waste Management \& Research, Vol. 25, Iss. 2, pp.162-169. http://dx.doi.org/10.1177/0734242X07075635

6. Gerardi, M. H. 2003. The microbiology of anaerobic digesters. John Wiley \& Sons, New York. http://dx.doi.org/10.1002/0471468967

7. Kabouris, J. C., Tezel, U., Pavlostathis, S. G., Engelmann, M., Todd, A. C., Gillette, R. A. 2008. The anaerobic biodegradability of municipal sludge and fat, oil, and grease at mesophilic conditions. Water Environment Research, Vol. 3, pp.12-221. $\underline{\text { http://dx.doi.org/10.2175/106143007x220699 }}$ 
8. Mathai, P., Turovskiy, I. 2006. Wastewater sludge processing. Wiley-Interscience, New York.

9. Monnet, F. 2003. An Introduction to Anaerobic Digestion of Organic Wastes. Technical Report, Scotland.

10. Rothman, K. J., Greenland, S. 1998. Modern Epidemiology, 2nd ed., Lippincot-Raven Publishers, New York. 